\title{
Study of Vitamin D Status in Pneumonia among Children between 6 Months to 3 Years of Age
}

\author{
Heba A. Ismail ${ }^{*}$, Esaad M. Menazie², Shimaa M. K. Ibrahim², Nashwa M. Abd Elbaky³ \\ ${ }^{1}$ Om-Almasreyyeen Hospital, Egyptian Ministry of Health, Giza, Egypt \\ ${ }^{2}$ Pediatrics Department, Faculty of Medicine for Girls, Al-Azhar University, Cairo, Egypt \\ ${ }^{3}$ Clinical Pathology Department, Faculty of Medicine for Girls, Al-Azhar University, Cairo, Egypt \\ Email: *Yahya.azab@cu.edu.eg
}

How to cite this paper: Ismail, H.A., Menazie, E.M., Ibrahim, S.M.K. and Elbaky, N.M.A. (2021) Study of Vitamin D Status in Pneumonia among Children between 6 Months to 3 Years of Age. Open Journal of Pediatrics, 11, 254-267.

https://doi.org/10.4236/ojped.2021.112025

Received: March 31, 2021

Accepted: June 5, 2021

Published: June 8, 2021

Copyright (c) 2021 by author(s) and Scientific Research Publishing Inc. This work is licensed under the Creative Commons Attribution International License (CC BY 4.0).

http://creativecommons.org/licenses/by/4.0/

\begin{abstract}
Background: In the developing world, pneumonia is not only more common than it is in Europe or North America; it is also more severe and considered the leading cause of under-five mortality. Effective management of pneumonia in children under 3-year-old-age is still challenging due to various causes. Some authors believed in non-calcemic role of vitamin D as a potential factor in the pathogenesis, prevention, or therapy of pneumonia in this specific age. Purpose: Investigate the Vitamin D status in pneumonia among children between 6 months to 3 years of age. Subjects and Methods: This study was conducted in a Pediatric point of care at Al-Zahraa University Hospital on 90 children aged 6 months to 3 years old; divided into two groups: group I (study group) including 47 patients presented with pneumonia and group II (control group) including 43 apparently healthy children of matched age and sex with no evidence of pneumonia. Serum vitamin D was estimated with specific inclusion and exclusion criteria. Results: The vitamin D level showed no significant difference between the two groups of the study. Conclusion: Possible role of vitamin D in disease process of pneumonia in children between 6 months to 3 years could not be assured.
\end{abstract}

\section{Keywords}

Pediatrics, LRTIs, $1,25(\mathrm{OH})_{2} \mathrm{D}$, Respiratory

\section{Introduction}

Pneumonia is the inflammation of the lung parenchyma caused by micro-organisms and is considered the leading cause of under-five mortality globally [1]. In the developing world, pneumonia is not only more common than it is in Europe and 
North America; it is also more severe and is the largest killer of children. Pneumonia accounts for $15 \%$ of all deaths of children under 5 years old, killing approximately 81,000 children in 2017 [1].

Vitamin D is a group of fat-soluble prohormones which were identified after the discovery of the anti-rachitic effect of cod liver oil in the $20^{\text {th }}$ century with the non-calcemic role of Vitamin D is well studied [2]. The respiratory airway epithelium can generate active vitamin D. Alveolar macrophages need to be stimulated before converting inactive to active vitamin $\mathrm{D}$ [3].

Toll-like receptor (TLR) 2/1 ligands (mycobacterial antigen) activate alveolar macrophages, induce 1a-hydroxylase and increase 1,25D which leads to an increase in the vitamin D regulated antimicrobial peptide cathelicidin [4].

Vitamin D deficient individuals also report more frequent respiratory tract infections perhaps due to less production of cathelicidin and/or increased production of chemokines leading to uncontrolled inflammatory response [5] [6].

In addition to well-researched functions in calcium homeostasis, Vitamin D modulates both the innate and the adaptive immune response and plays a key role in the balance between T-helper 1 and T-helper 2 (Th1-Th2) cytokines [7] [8]. It has been shown that VD decreases the pro-inflammatory type 1 cytokines: IL-12, interferon-gamma (IFN- $\gamma$ ), IL-6, IL-8, tumor necrosis factor alpha (TNF $\alpha$ ) and IL-17 and increase anti-inflammatory IL-10 and Th2 cytokines: IL-4 and IL-5 [9] [10].

On the other hand, a total of five aggregate data meta-analyses incorporating data from up to 15 primary trials have been conducted to date of effect of vitamin D, of which two report statistically significant protective effects [11] but thirteen report no statistically significant effects [12].

Vitamin D status is categorized based on endocrine society guidelines as deficiency, insufficiency, and sufficiency based on serum 25-OH Vitamin D levels below $20 \mathrm{ng} / \mathrm{ml}(50 \mathrm{nmol} / \mathrm{L}), 21-29 \mathrm{ng} / \mathrm{ml}(52.5-72.5 \mathrm{nmol} / \mathrm{L})$, and $30-100$ $\mathrm{ng} / \mathrm{ml}(75-250 \mathrm{nmol} / \mathrm{L})$, respectively. Although this classification is accepted widely, extensive efforts are being taken to interpret the basis of this criteria as most of the global populations are found to be Vitamin D deficient [13].

Our hypothesis was vitamin D levels in children with pneumonia may be below normal documented reference range, therefore.

\section{Aim of the Work}

To investigate the vitamin D status in children with pneumonia aged 6 months to 3 years as a trial to examine possible role of vitamin D status in the disease process of pneumonia.

\section{Patients and Methods}

This was a cross sectional observational study carried on 47 patients diagnosed with pneumonia and aged from 6 months to 3 years old, selected from pediatric department point of care, Al-Zahraa University Hospital and in the period from 
January 2020 to July 2020. Another 43 apparently healthy children with matched age and sex of the patients group.

All children in the study are sequentially enrolled according to the study design and the inclusion criteria and classified as follow:

\subsection{Inclusion Criteria}

- Case groups:

All patients in the group I must fulfill the following criteria:

- Age: from 6 month to 3 years.

- Sex: both sexes were included, presented by signs and symptoms of pneumonia (cough, fever, dyspnea, etc.) confirmed by positive radiological and/or culture results and admitted to the pediatric department point of care.

Patients were free from other infectious diseases than pneumonia, fat absorption problems, hepatic and renal impairments.

Patients did not receive oral vitamin D supplementation in the last 2 weeks before admission.

- Controls:

Forty-three apparently healthy children with matched age and sex ofpatients groups with no evidence of pneumonia or history of lower respiratory tract infection.

\subsection{Exclusion Criteria}

- Children with rickets.

- Children deliver vitamin D supplementation.

- Children under or more than this specified age range.

- Children with other diseases other than pneumonia (liver, kidney).

- Children with bronchial asthma.

- Immune compromised patients or receiving immunosuppressive drugs.

\section{Methods}

All patients in the study were subjected to full history taking with special emphasis on respiratory system according to Al-Zahraa Admission Clinical sheet. Thorough clinical examination was performed. Laboratory investigation on admission. Five mls venous blood was drawn using standard venipuncture techniques and divided into:

1) A specimen on EDTA tubes for

a) Complete blood count (CBC).

b) Qualitative C-reactive protein (CRP).

c) ESR.

2) A specimen on plain tubes for

a) Calcium, Phosphorus.

b) ALT, AST, urea, creatinine assessments on the day using HITACHI automatic analyzer. 
Chest X-ray was performed (lateral and posterio-anterior views). Serum was stored at $-4^{\circ} \mathrm{C}$ for 24 hours or at $-20^{\circ} \mathrm{C}$ for long term storage to for analysis of $25(\mathrm{OH})$ vit. D level by specific ELISA kit. 25(OH) vit. D level was reported in $\mathrm{ng} / \mathrm{ml}$, which can be multiplied by 2.496 to be converted to nmol/l [14].

Assessment of Serum 25 hydroxy vitamin D in all studied children was done using enzyme_linked_immunoassay (ELISA) kit delivered by Dia Metra Bioscience Laboratory. Vitamin D status was assessed by measurement of serum 25-Hydroxy vitamin D (25(OH)D) according to Endocrine society guidelines [13].

\subsection{Statistical Analysis}

Estimated data were analyzed by R software; statistical package for social sciences, version 3.6.3 (R 3.6.3, Bell Labs, New Jersey, USA). Quantitative data were expressed as median \pm inter quartile range (IQR) while qualitative data were expressed as frequency and percentage. Independent-samples t-test of significance was used for comparing between two means if data was parametric and Two-group Mann-Whitney U Test between normal and diseased groups of children with pneumonia compared between medians of two groups of the study if data was non-parametric, respectively. While Chi-square $\left(X^{2}\right)$ test was used in comparison between qualitative parameters. The confidence interval was set to $95 \%$ and $5 \%$ was the margin error. So, the $p$-value $<0.05$ was considered significant, $p$-value $<0.001$ was highly significant and $p$-value $>0.05$ was insignificant.

\subsection{Ethical Consideration}

Approvalon the study protocol by ethical committee of faculty of Medicine for Girls-Al-Azhar University was obtained.

An informed oral consent was obtained from all parents of patients before getting them involved in this studyexplaining the objectives of the study, the expected benefits, and types of information to them.

All the data and results of the study are confidential, and the participants had right to keep it.

The patient has the right to withdraw from the study at any time.

\section{Results}

\subsection{Descriptive Data of Patient Groups}

This is cross-sectional study performed on (90) children divided into (43) apparently healthy children represented as control group and (47) diseased children with WHO-defined pneumonia represented as diseased group attending outpatient department at Al-Zahraa University hospital. Both groups of children aged from 6 months to 3 years.

\subsection{Age}

According to independent 2-group Mann-Whitney U Test, there was no significant difference in age between normal children and diseased children with 
pneumonia $(\mathrm{w}=1096.5, p$-value $=0.48)$ as shown in Table 1 .

\subsection{Sex}

A chi square test of independence indicated that there is no significant relationship between sex in control health and diseased children, $X^{2}(1, \mathrm{~N}=90)=2.089$, $p=0.148$ as shown in Table 2 .

\subsection{Chest Radiography}

A chi square test of independence was used to compare the chest $\mathrm{X}$ ray between healthy and diseased child (pneumonia). Chest $\mathrm{X}$ ray was significantly related to health condition of child. Diseased child tended to have more infiltration and consolidation of lungs than healthy child (normal lung $X$ ray) $\left(X^{2}(2, \mathrm{~N}=90)=\right.$ 90, $p<0.001)$ as shown in Table 3.

\subsection{Vitamin D Concentration}

There was no significant difference in vitamin $\mathrm{D}$ concentration $(\mathrm{ng} / \mathrm{ml})$ between normal children and diseased children with pneumonia with both groups showed higher levels of vitamin $\mathrm{D}(>20 \mathrm{ng} / \mathrm{ml}, \mathrm{w}=846.5, p$-value $=0.19)$ as shown in Table 4.

Table 1. Age of child in control (healthy child) and pneumonia (diseased child).

\begin{tabular}{cccccc}
\hline & Control & Pneumonia & & & \\
\cline { 2 - 3 } Parameters & $\begin{array}{c}\text { Median } \pm \text { IQR } \\
(\mathrm{LCL}-\mathrm{UCL})\end{array}$ & $\begin{array}{c}\text { Median } \pm \text { IQR } \\
\text { (LCL }- \text { UCL })\end{array}$ & W & $\begin{array}{c}\text { Effect size } \\
\text { (Cliffs Delta) }\end{array}$ & $p$-value \\
\cline { 2 - 3 } Age (months) & $\begin{array}{c}12 \pm 15 \\
(13.10-18.85)\end{array}$ & $\begin{array}{c}12 \pm 9 \\
(11.55-15.73)\end{array}$ & 1096.5 & 0.09 & ns $(0.48)$ \\
\hline
\end{tabular}

Table 2. Sex in control (healthy child) and pneumonia (diseased child).

\begin{tabular}{cccccc}
\hline \multirow{2}{*}{ Group } & \multicolumn{2}{c}{ Sex } & Total \\
\cline { 2 - 3 } & Female $(\mathrm{n}=45)$ & Male $(\mathrm{n}=45)$ & $X^{2}$ & $p$-value \\
Control & $22(48.9 \%)$ & $21(46.7 \%)$ & $\mathrm{n}=43$ & & 0.833 \\
Pneumonia & $23(51.1 \%)$ & $24(53.3 \%)$ & $\mathrm{n}=47$ & 0.044 & \\
\hline
\end{tabular}

Table 3. Chest X ray in control (healthy child) and pneumonia (diseased child).

\begin{tabular}{|c|c|c|c|c|c|c|}
\hline \multirow[b]{2}{*}{ Group } & \multicolumn{3}{|c|}{ Chest $\mathrm{X}$ ray } & \multirow[b]{2}{*}{$\begin{array}{c}\text { Total } \\
(\mathrm{n}=90)\end{array}$} & \multirow[b]{2}{*}{$X^{2}$} & \multirow[b]{2}{*}{$p$-value } \\
\hline & $\begin{array}{l}\text { Normal } \\
(\mathrm{n}=43)\end{array}$ & $\begin{array}{l}\text { Infiltration } \\
\quad(\mathrm{n}=35)\end{array}$ & $\begin{array}{c}\text { Consolidation } \\
\quad(\mathrm{n}=12)\end{array}$ & & & \\
\hline Control & $43(100 \%)$ & $0(0 \%)$ & $0(0 \%)$ & $\mathrm{n}=43$ & & \\
\hline Pneumonia & $0(0 \%)$ & 35 (74.5\%) & $12(25.5 \%)$ & $\mathrm{n}=47$ & 90 & $<0.001$ \\
\hline
\end{tabular}




\subsection{Hb, Leukogram and Biochemical Parameters}

There was a significant difference in $\mathrm{Hb}(\mathrm{g} / \mathrm{dl})$, TLC $\left(\times 10^{3} / \mathrm{ml}\right)$, neutrophil (\%), eosinophil (\%), lymphocytes $(\%)$, platelets $\left(\times 10^{3} / \mathrm{ml}\right)$, urea $(\mathrm{mg} / \mathrm{ml})$ and creatinine $(\mathrm{mg} / \mathrm{ml})$, AST (U/L) between control children and diseased child with pneumonia groups as shown in Table 5 . There was no significant difference in basophil (\%), ALP (IU) and ALT (U/L) between control children and diseased children with pneumonia groups as shown in Table 5 and Table 6.

Table 4. Median concentration of vitamin $\mathrm{D}(\mathrm{ng} / \mathrm{ml})$ in control and pneumonia children.

\begin{tabular}{|c|c|c|c|c|c|}
\hline & Control & Pneumonia & & & \\
\hline Parameter & $\begin{array}{c}\text { Median } \pm \text { IQR } \\
\text { (LCL - UCL) }\end{array}$ & $\begin{array}{c}\text { Median } \pm \text { IQR } \\
(\mathrm{LCL}-\mathrm{UCL})\end{array}$ & W & $\begin{array}{c}\text { Effect size } \\
\text { (Cliff's Delta) }\end{array}$ & $p$-value \\
\hline $\begin{array}{l}\text { Vitamin D } \\
(\mathrm{ng} / \mathrm{ml})\end{array}$ & $\begin{array}{l}24.09 a \pm 28.33 \\
(23.65-37.60)\end{array}$ & $\begin{array}{l}29.78 a \pm 32.49 \\
(28.96-42.19)\end{array}$ & 846.5 & -0.16 & Ns (0.19) \\
\hline
\end{tabular}

Ns: no significance. Data represented as median $\pm \mathrm{IQR}$, row with different superscript were statistically significant at $p$-value $\leq 0.05$ (independent 2-group Mann-Whitney $\mathrm{U}$ Test, R 3.6.3, w value, Effect size (Cliff's Delta), $p$-value).

Table 5. Hb, leukogram and biochemical parameters in control (normal child) and pneumonia (diseased child).

\begin{tabular}{|c|c|c|c|c|c|}
\hline & Control & Pneumonia & & & \\
\hline Parameters & $\begin{array}{c}\text { Median } \pm \text { IQR } \\
(\mathrm{LCL}-\mathrm{UCL})\end{array}$ & $\begin{array}{c}\text { Median } \pm \mathrm{IQR} \\
(\mathrm{LCL}-\mathrm{UCL})\end{array}$ & $\mathrm{W}$ & $\begin{array}{c}\text { Effect size } \\
\text { (Cliff's Delta) }\end{array}$ & $p$-value \\
\hline $\mathrm{Hb}(\mathrm{g} / \mathrm{dl})$ & $\begin{array}{c}11.60^{\mathrm{a}} \pm 2.30 \\
(11.33-12.22)\end{array}$ & $\begin{array}{l}10.00^{\mathrm{b}} \pm 2.10 \\
(9.84-10.77)\end{array}$ & 1535 & 0.52 & $<0.001$ \\
\hline $\mathrm{TLC}\left(\times 10^{3} / \mathrm{ml}\right)$ & $\begin{array}{l}8.00^{\mathrm{a}} \pm 2.93 \\
(7.42-8.58)\end{array}$ & $\begin{array}{c}12.00^{\mathrm{b}} \pm 3.58 \\
(11.21-14.39)\end{array}$ & 285.5 & 0.72 & $<0.001$ \\
\hline Neutrophil (\%) & $\begin{array}{l}48.80^{\mathrm{a}} \pm 17.20 \\
(46.78-55.37)\end{array}$ & $\begin{array}{l}37.80^{\mathrm{b}} \pm 21.55 \\
(35.61-44.27)\end{array}$ & 1450 & 0.43 & $<0.001$ \\
\hline Eosinophil (\%) & $\begin{array}{l}0.50^{\mathrm{a}} \pm 1.35 \\
(0.46-1.02)\end{array}$ & $\begin{array}{l}1.00^{\mathrm{b}} \pm 1.95 \\
(1.18-2.24)\end{array}$ & 658 & -0.35 & $<0.01$ \\
\hline Basophil (\%) & $\begin{array}{l}0.00^{\mathrm{a}} \pm 0.50 \\
(0.14-0.38)\end{array}$ & $\begin{array}{l}0.00^{\mathrm{a}} \pm 1.00 \\
(0.36-0.93)\end{array}$ & 823 & -0.19 & Ns (0.09) \\
\hline Lymphocyte (\%) & $\begin{array}{c}31.43^{c} \pm 1.73 \\
(28.04-34.82)\end{array}$ & $\begin{array}{c}44.44^{\mathrm{d}} \pm 2.60 \\
(39.34-49.55)\end{array}$ & -4.09 & 0.86 & $<0.001$ \\
\hline $\operatorname{PLT}\left(\times 10^{3} / \mathrm{ml}\right)$ & $\begin{array}{c}272.02^{\mathrm{c}} \pm 14.15 \\
(244.29-299.76)\end{array}$ & $\begin{array}{c}379.28^{\mathrm{d}} \pm 20.38 \\
(339.34-419.21)\end{array}$ & -4.25 & 0.89 & $<0.001$ \\
\hline
\end{tabular}

Hb: Hemoglobin; TLC: total leucocytic count; PLT: platelet count; ${ }^{\mathrm{a}, \mathrm{b}}$ Data represented as median $\pm \mathrm{IQR}$, row with different superscript were statistically significant at $p$-value $\leq 0.05$ (independent 2-group Mann-Whitney $\mathrm{U}$ Test, R 3.6.3); ${ }^{\mathrm{c}, \mathrm{d}}$ Data represented as mean \pm SEM, LCL-lower confidence limit for mean, UCL-upper confidence limit for mean, row with different superscript were statistically significant at $p$-value $\leq 0.05$ (independent T-test, R 3.6.3, t value, Effect size (Cohen's d), p-value). 


\subsection{Erythrocyte Sedimentation Rate}

There was no significant difference in ESR between control children and diseased children with pneumonia groups as shown in Table 7.

\subsection{C-Reactive Protein}

A chi square test of independence was calculated comparing the presence of CRP in healthy and diseased child. Significant interaction was found $\left(X^{2}(1, \mathrm{~N}=90)=\right.$ $0.045, p=0.001)$ between CRP and health condition of the child as shown in Table 8.

\subsection{Method of Breast Feeding}

A chi square test of independence indicated that there is no significant relationship between the method of feeding (breast or bottle feeding) and health condition of the child, $X^{2}(1, \mathrm{~N}=90)=2.089, p=0.148$ as shown in Table 9 .

Table 6. Liver and kidney enzymes between control and pneumonia groups of the study.

\begin{tabular}{|c|c|c|c|c|c|}
\hline \multirow[b]{2}{*}{ Parameters } & Control & Pneumonia & \multirow[b]{2}{*}{ W } & \multirow{2}{*}{$\begin{array}{c}\text { Effect size } \\
\text { (Cliff's Delta) }\end{array}$} & \multirow[b]{2}{*}{$p$-value } \\
\hline & $\begin{array}{c}\text { Median } \pm \text { IQR } \\
\text { (LCL - UCL) }\end{array}$ & $\begin{array}{c}\text { Median } \pm \text { IQR } \\
(\mathrm{LCL}-\mathrm{UCL})\end{array}$ & & & \\
\hline AST (U/L) & $\begin{array}{c}23.44^{\mathrm{c}} \pm 1.46 \\
(20.58-26.31)\end{array}$ & $\begin{array}{c}27.68^{\mathrm{d}} \pm 1.53 \\
(24.67-30.69)\end{array}$ & -1.99 & 0.42 & $<0.05$ \\
\hline ALP (IU) & $\begin{array}{l}492.00^{\mathrm{a}} \pm 87.00 \\
(490.9-527.7)\end{array}$ & $\begin{array}{c}522.00^{\mathrm{a}} \pm 103.50 \\
(502 .-540.32)\end{array}$ & 902.5 & -0.11 & Ns (0.39) \\
\hline $\operatorname{ALT}(\mathrm{U} / \mathrm{L})$ & $\begin{array}{l}23.00^{\mathrm{a}} \pm 10.50 \\
(19.78-26.50)\end{array}$ & $\begin{array}{l}21.00^{\mathrm{a}} \pm 14.50 \\
(19.77-25.92)\end{array}$ & 918.5 & -0.09 & Ns $(0.46)$ \\
\hline Urea $(\mathrm{mg} / \mathrm{ml})$ & $\begin{array}{l}22.00^{\mathrm{a}} \pm 12.50 \\
(19.36-24.03)\end{array}$ & $\begin{array}{l}29.00^{\mathrm{b}} \pm 11.00 \\
(25.11-29.27)\end{array}$ & 609.5 & -0.4 & $<0.001$ \\
\hline Creatinine $(\mathrm{mg} / \mathrm{ml})$ & $\begin{array}{c}0.50^{\mathrm{a}} \pm 0.2 \\
(0.45-0.53)\end{array}$ & $\begin{array}{c}0.60^{\mathrm{b}} \pm 0.2 \\
(0.56-0.64)\end{array}$ & 711.5 & -0.29 & $<0.05$ \\
\hline
\end{tabular}

AST: Aspartate aminotransferase; ALP: Alkaline phosphatase; ALT: Alanine transaminase; a,b Data represented as median $\pm \mathrm{IQR}$, row with different superscript were statistically significant at $p$-value $\leq 0.05$ (independent 2-group Mann-Whitney U Test, R 3.6.3); ${ }^{c, d}$ Data represented as mean \pm SEM, LCL-lower confidence limit for mean, UCL-upper confidence limit for mean, row with different superscript were statistically significant at $p$-value $\leq 0.05$ (independent T-test, $\mathrm{R} 3.6 .3$, $\mathrm{t}$ value, Effect size (Cohen's $\mathrm{d}$ ), $p$-value).

Table 7. Erythrocyte sedimentation rate (ESR) between control and pneumonia groups of the study.

\begin{tabular}{ccccccc}
\hline \multirow{2}{*}{ Parameters } & Control & Pneumonia & & & \\
\cline { 2 - 3 } & $\begin{array}{c}\text { Median } \pm \text { IQR } \\
(\mathrm{LCL}-\mathrm{UCL})\end{array}$ & $\begin{array}{c}\text { Median } \pm \mathrm{IQR} \\
(\mathrm{LCL}-\mathrm{UCL})\end{array}$ & W & $\begin{array}{c}\text { Effect size } \\
\text { (Cliffs Delta) }\end{array}$ & $p$-value \\
\hline \multirow{2}{*}{ ESR } & $\begin{array}{c}9.00^{\mathrm{a}} \pm 4.50 \\
(7.52-9.92)\end{array}$ & $\begin{array}{c}18.00^{\mathrm{b}} \pm 12.00 \\
(16.41-24.05)\end{array}$ & 289.5 & -0.71 & $<0.001$ \\
\hline
\end{tabular}

${ }^{\mathrm{a}, \mathrm{b}}$ Data represented as median $\pm \mathrm{IQR}$, row with different superscript were statistically significant at $p$-value $\leq 0.05$ (independent 2-group Mann-Whitney U Test, R 3.6.3). 
Table 8. C-reactive protein (CRP) in control (healthy child) and pneumonia (diseased child).

\begin{tabular}{cccccc}
\hline \multirow{2}{*}{ Group } & \multicolumn{2}{c}{ CRP } & Total \\
\cline { 2 - 4 } & Negative $(\mathrm{n}=45)$ & Positive $(\mathrm{n}=45)$ & $X^{2}$ & $p$-value \\
\hline Control & $43(100 \%)$ & 0 & $\mathrm{n}=43$ & \\
Pneumonia & $24(51 \%)$ & $23(49 \%)$ & $\mathrm{n}=47$ & 0.045 & 0.001 \\
\hline
\end{tabular}

Table 9. Bottle and breast feeding in control (healthy child) and pneumonia (diseased child).

\begin{tabular}{cccccc}
\hline \multirow{2}{*}{ Group } & \multicolumn{2}{c}{ Feeding } & Total & Bal \\
\cline { 2 - 4 } & Bottle $(\mathrm{n}=41)$ & Breast $(\mathrm{n}=49)$ & $X^{2}$ & $p$-value \\
\hline Control & $23(56.10 \%)$ & $20(40.80 \%)$ & $\mathrm{n}=43$ & 2.089 & 0.148 \\
Pneumonia & $18(43.90 \%)$ & $29(59.20 \%)$ & $\mathrm{n}=47$ & & \\
\hline
\end{tabular}

\section{Discussion}

We conducted our study on 90 candidates; 47 as study group have pneumonia and admitted to the pediatric department point of care, Al-Zahraa Hospital University while the other candidates comprise the control group. This study measured vitamin D levels among sera of two groups of children aged 6 months to 3 years to investigate whether there is a significant difference between vitamin $\mathrm{D}$ status in the two groups of the study. So, our study camein agreement to data collected from 15 primary trials have been conducted, of which two report statistically significant protective effects while, thirteen report no statistically significant effects [15].

All but one of these aggregate data meta-analyses [16] reported statistically significant heterogeneity of effect between primary trials. This heterogeneity might have arisen as a result of variation in participant characteristics and dosing regimens between trials, either of which may modify the effects of vitamin $\mathrm{D}$ supplementation on immunity to respiratory pathogens [17].

A recent Cochrane review evaluated 4 studies involving 780 children with pneumonia and 3 studies including 749 children with severe or very severe pneumonia, all aged $<5$ years. Various doses and methods of administration of VD were used, but, because of low and very low-quality evidence, the reviewers remained uncertain as to whether oral vitamin $\mathrm{D}$ as an adjunct to treatment of acute pneumonia in children $<5$ years influences outcome [18].

Gupta et al., [19] concluded that there is no robust evidence of a definite biological benefit, either for therapy or prevention, to suggest a routine megadose supplement of vitamin D3 for under-five children with severe pneumonia in a trial to study the efficacy of single oral mega-dose of Vitamin D3 for treatment and prevention of pneumonia in 980 under-five children.

Prenatal VD supplementation did not affect the development of asthma and 
RW at the age of 6 years [20]. These results suggest that antenatal supplementation alone does not provide adequate protection, and postnatal supplementation is needed. In a meta-analysis of data from 16 birth cohorts, Feng et al., [21] showed that increased antenatal exposure to $25(\mathrm{OH}) \mathrm{D}$ is inversely related to the risk of asthma and wheeze in the offspring, but not respiratory tract infections.

Yakoob, Salam, Khan and Bhutta [22] who found that one large trial did not demonstrate benefit of vitamin $\mathrm{D}$ supplementation on the incidence of pneumonia or diarrhea in children less than five years.

Remmelts et al., [23] in a prospective cohort study on hospitalized patients with CAP stated that vitamin D deficiency was associated with an increased risk of ICU admission and 30-day mortality.

Amrein et al., [24] noticed that among critically ill patients with vitamin D deficiency, administration of high-dose vitamin D3 compared with placebo did not reduce hospital length of stay, hospital mortality, or 6-month mortality. In addition, [25] stated that short-term supplementation with oral vitamin D has no beneficial effect on resolution of severe pneumonia in under-five children. Moreover, Selvarajan et al., [13] stated that most of the global populations are found to be Vitamin D deficient.

In disagreement with our study done by Mamani, Muceli, Ghasemi Basir, Vasheghani and Poorolajal [26], a low level of $25(\mathrm{OH}) \mathrm{D}$ is associated with a higher incidence of community-acquired pneumonia and more severe disease. As well as the study done by Özdemir, Köksal, Karakaş, Tekindal and Özbek Ö [27] found significantly low serum 25(OH)D levels in children with recurrent respiratory infections (RRI).

In contrary to our results in a study done by (Kim et al., 2015) show the prevalence of vitamin D deficiency was approximately $80 \%$ in patients hospitalized with community acquired pneumonia. (Aregbesola et al., 2013) found that the subjects with the lowest level of serum 25(OH)D had a significant 2.6-fold (95\% CI: 1.4, 5.0) higher risk of developing pneumonia compared to the subjects with the highest levels. They concluded that there was an inverse effect of serum $25(\mathrm{OH}) \mathrm{D}$ concentration on the risk of incident pneumonia in the aging population.

Mao and Huang [16] reported statistically significant heterogeneity between vitamin D primary trials. This heterogeneity might have arisen as a result of variation in participant characteristics and dosing regimens between trials, either of which may modify the effects of vitamin D supplementation on immunity to respiratory pathogens [17].

Control children were (22) females (51.2\%) and (21) males (48.8\%), while children presented with pneumonia were (23) females (48.9\%) and (24) males (51.1\%). Opposite to Naheed, Breiman, Islam, Saha and Tabassum Naved [28] founded higher proportion of hospitalized females had very severe pneumonia as compared to males $(21.5 \%$ versus $19.1 \% ; p=0.01)$, but there was no difference by sex in the proportion of children with severe or non-severe pneumonia. 
Death in female children admitted with very severe pneumonia was 4 times higher than that reported in males. Similarly, in a study by Del Rosal et al., [29] in Madrid, Spain. Some authors explained this notion may be due to care-seeking behaviors of the parents of children with pneumonia prior to hospitalization superior to males [28].

On the other hand, Yancey, Watson, Cartner and Simecka [30] noticed that there was no gender difference in disease severity along the airways or any difference in mycoplasma numbers in lungs of male and female mice despite, surgical removal of reproductive organs reduced the severity of mycoplasma disease and the numbers of mycoplasma organisms recovered from lungs.

Seventy-four and half $(74.5 \%)$ percent of the patients suffered from pneumonia in from 6 - 18 months of age while (25.5\%) of them included between 1.5 year to 3 years old. Similarly was conducted by [31] and could be explained by diminished vitamin $\mathrm{D}$ levels after 6 months of age due to poor supply achieved from mother's milk beside shortage of body reserve in additions to decreased outdoor exposure to sun light in this age range as explained by [32].

There was decreasing in the mean value of $\mathrm{Hb}$ below $10 \mathrm{~g} / \mathrm{dl}$ in group of pneumonia children with significant difference with the control group (11.6 $\mathrm{g} / \mathrm{dl}, p<0.001)$. This may be due to anemia of infection which causes defective heme synthesis because of block in release of iron from macrophages to developing normoblast. These data came in agree with Feldstein et al., [33] who found anemia in hospitalized children with lower respiratory tract infection.

Anemic children were two times more susceptible to lower respiratory tract infection compared to the control group, and iron deficiency anemia was predominating [34]. The explanation for this pathophysiological deficit in ARTIs is that the central is poor tissue oxygenation and anemia independently decreases oxygen delivery which results in more disease and more hospitalization [35].

In the present study, total leucocytic count was higher than normal reference ranges in $(21 / 47$ children, $44.7 \%)$ in diseased children. Relatively similar, the sensitivity of TLC in the diagnosis of CAP was $48.5 \%$ [36].

There was significant increase in ESR (median $=18$ ) in pneumonia group when compared to control group. This increase could be attributed to the plasma proteins, such as fibrinogen, alpha-1 antitrypsin and C-reactive protein (CRP), that increase during inflammation and coat the RBCs, thus minimizing their electronegative charge, and allowing rouleaux to occur and increase ESR [37]. In the present study, 23 children (49\%) with pneumonia showed positive CRP while it is absent in control healthy children. This is in contrast with [36] who suggest sensitivity of CRP in diagnosis of pneumonia to be $72 \%$. This controversy may be difference in causes (viral or bacterial) of majority of cases in each study.

Out of 47 diseased children in the present study, 11 diseased children (23\%) to a large extent suspected to be of bacterial cause as those showed concurrent neutrophilia, positive CRP, and consolidation on radiographs. Ten diseased children 
(21\%) to a large extent suspected to be of viral cause as those showed concurrent lymphocytosis or lymphopenia, negative CRP, and infiltration on radiographs. Don [38] stated that CRP, WBC count, and ESR or their combinations have a limited role in screening between bacterial and viral pediatric CAP and added that if all or most of these markers are elevated, bacterial etiology is highly probable, but low values do not rule out bacterial etiology. In contrast to Dhairya Lakhani [36] who reported that the sensitivity of CRP, ESR and TLC in the diagnosis of CAP were $90.9 \%, 72.7 \%$ and $48.5 \%$.

As for breast feeding,in disagreement with our study, some authors found that prolonged exclusive breast feeding is an important and significant contributary factor for pneumonia in children [39] [40]. Against our study, Tan, Abrams and Osborn [41] who suggested that serum $25(\mathrm{OH}) \mathrm{D}$ concentration in breast fed children were significantly lower than in children from the other feeding groups.

\section{Conclusion}

The failure of the majority of studies to prove vitamin D's role in prevention, augmentation of pneumonia in children is obviously confusing. From the present authors' experience, we suggested that the present controversy in results and conclusions of various studies will be continued due to the nature of the subject. Vitamin D is highly affected by over 50 risk factors that could not be controlled all at the same time besides many existing causes that also may be multiple. Vitamin D levels in blood depending on sun exposure making children from different governorates in the same country especially Egypt showed massive variation in those levels despite proving some of the role of vitamin $\mathrm{D}$ in modulation of respiratory system immunity.

\section{Study Limitations}

Pneumonia is a multifactorial disease, so the study could not measure all factors predisposing to this disease and only focus to measure vitamin D levels in the sera.

\section{Acknowledgements}

Many thanks must be drawn to all doctors and nurses of pediatric department at Al-Zahraa Hospital.

Authors declare no source of any financial support was received and recognition of personal assistance for the work.

\section{Conflicts of Interest}

The authors declare no conflicts of interest regarding the publication of this paper.

\section{References}

[1] Yadav, R.K., Kumar, D., Singh, A., Ziauddin, M. and Singh, D.K. (2021) Clinical 
and Microbial Spectrum of Community-Acquired Pneumonia in Children of North India. Tropical Doctor, 51, 71-77. https://doi.org/10.1177/0049475520971595

[2] Rabee, M.A., El Nahass, N.G., Abdeen, H.A. and El Kader, F.A. (2020) Efficacy of Interval Training on Quality of Life in Women with Vitamin D Deficiency. Medical Journal of Cairo University, 88, 1507-1512.

https://doi.org/10.21608/mjcu.2020.116241

[3] Ensinck, G., Lazarte, G., Ernst, A., et al. (2021) Community-Acquired Methicillin-Resistant Staphylococcus aureus Pneumonia in a Children's Hospital. Our Ten-Year Experience. Archivos Argentinos de Pediatria, 119, 11-17.

https://doi.org/10.5546/aap.2021.eng.11

[4] Carloni, I., Ricci, S., Rubino, C., et al. (2021) Necrotizing Pneumonia among Italian Children in the Pneumococcal Conjugate Vaccine Era. Pediatric Pulmonology, 56, 1127-1135. https://doi.org/10.22541/au.159836223.33683043

[5] Panfili, F.M., Roversi, M., D’argenio, P., et al. (2021) Possible Role of Vitamin D in Covid-19 Infection in Pediatric Population. Journal of Endocrinological Investigation, 44, 27-35. https://doi.org/10.1007/s40618-020-01327-0

[6] Shojaeefar, E., Malih, N. and Rezaei, N. (2021) The Possible Double-Edged Sword Effects of Vitamin D on COVID-19: A Hypothesis. Cell Biology International, 45, 54-57. https://doi.org/10.1002/cbin.11469

[7] Carlberg, C. (2018) Vitamin D Genomics: From in Vitro to in Vivo. Frontiers in Endocrinology (Lausanne), 9, 250. https://doi.org/10.3389/fendo.2018.00250

[8] Lipińska-Opałka, A., Tomaszewska, A., Kubiak, J.Z. and Kalicki, B. (2021) Vitamin D and Immunological Patterns of Allergic Diseases in Children. Nutrients, 13, 177. https://doi.org/10.3390/nu7064240

[9] Greiller, C.L. and Martineau, A.R. (2015) Modulation of the Immune Response to Respiratory Viruses by Vitamin D. Nutrients, 7, 4240-4270.

https://doi.org/10.3390/nu7064240

[10] Bleakley, A.S., Licciardi, P.V. and Binks, M.J. (2021) Vitamin D Modulation of the Innate Immune Response to Paediatric Respiratory Pathogens Associated with Acute Lower Respiratory Infections. Nutrients, 13, 276.

https://doi.org/10.3390/nu13010276

[11] Costenaro, P., Cantarutti, A., Barbieri, E., et al. (2021) Antibiotic Prescriptions for Children with Community-acquired Pneumonia: Findings from Italy. The Pediatric Infectious Disease Journal, 40, 130-136. https://doi.org/10.1097/INF.0000000000002934

[12] Xiao, L., Xing, C., Yang, Z., et al. (2015) Vitamin D Supplementation for the Prevention of Childhood Acute Respiratory Infections: A Systematic Review of Randomised Controlled Trials. British Journal of Nutrition, 114, 1026-1034. https://doi.org/10.1017/S000711451500207X

[13] Selvarajan, S., Gunaseelan, V., Anandabaskar, N., et al. (2017) Systematic Review on Vitamin D Level in Apparently Healthy Indian Population and Analysis of Its Associated Factors. Indian Journal of Endocrinology and Metabolism, 21, 765-775. https://doi.org/10.4103/ijem.IJEM_168_17

[14] Angelidi, A.M., Belanger, M.J., Lorinsky, M.K., et al. (2021) Vitamin D Status Is Associated with In-Hospital Mortality and Mechanical Ventilation: A Cohort of COVID-19 Hospitalized Patients. Mayo Clinic Proceedings, 96, 875-886. https://doi.org/10.1016/j.mayocp.2021.01.001

[15] Martineau, A.R., Jolliffe, D.A., Hooper, R.L., et al. (2017) Vitamin D Supplementation to Prevent Acute Respiratory Tract Infections: Systematic Review and Me- 
ta-Analysis of Individual Participant Data. BMJ, 356, i6583.

[16] Mao, S. and Huang, S. (2013) Vitamin D Supplementation and Risk of Respiratory Tract Infections: A Meta-Analysis of Randomized Controlled Trials. Scandinavian Journal of Infectious Diseases, 45, 696-702. https://doi.org/10.3109/00365548.2013.803293

[17] Vuichard Gysin, D., Dao, D., Gysin, C.M., Lytvyn, L. and Loeb, M. (2016) Effect of Vitamin D3 Supplementation on Respiratory Tract Infections in Healthy Individuals: A Systematic Review and Meta-Analysis of Randomized Controlled Trials. PLoS ONE, 11, e0162996. https://doi.org/10.1371/journal.pone.0162996

[18] Das, R.R., Singh, M. and Naik, S.S. (2018) Vitamin D as an Adjunct to Antibiotics for the Treatment of Acute Childhood Pneumonia. Cochrane Database of Systematic Reviews, 7, Cd011597. https://doi.org/10.1002/14651858.CD011597.pub2

[19] Gupta, P., Dewan, P., Shah, D., et al. (2016) Vitamin D Supplementation for Treatment and Prevention of Pneumonia in Under-Five Children: A Randomized Double-Blind Placebo Controlled Trial. Indian Pediatrics, 53, 967-976. https://doi.org/10.1007/s13312-016-0970-5

[20] Litonjua, A.A., Carey, V.J., Laranjo, N., et al. (2020) Six-Year Follow-Up of a Trial of Antenatal Vitamin D for Asthma Reduction. The New England Journal of Medicine, 382, 525-533. https://doi.org/10.1056/NEJMoa1906137

[21] Feng, X., Wu, H., Grossman, J.M., et al. (2006) Association of Increased Interferon-Inducible Gene Expression with Disease Activity and Lupus Nephritis in Patients with Systemic Lupus Erythematosus. Arthritis \& Rheumatism, 54, 2951-2962. https://doi.org/10.1002/art.22044

[22] Yakoob, M.Y., Salam, R.A., Khan, F.R. and Bhutta, Z.A. (2016) Vitamin D Supplementation for Preventing Infections in Children under Five Years of Age. Cochrane Database of Systematic Reviews Review, 11, Cd008824. https://doi.org/10.1002/14651858.CD008824.pub2

[23] Remmelts, H.H., Spoorenberg, S.M., Oosterheert, J.J., et al. (2013) The Role of Vitamin D Supplementation in the Risk of Developing Pneumonia: Three Independent Case-Control Studies. Thorax, 68, 990-996. https://doi.org/10.1136/thoraxjnl-2013-203623

[24] Amrein, K., Scherkl, M., Hoffmann, M., et al. (2020) Vitamin D Deficiency 2.0: An Update on the Current Status Worldwide. European Journal of Clinical Nutrition, 74, 1498-1513. https://doi.org/10.1038/s41430-020-0558-y

[25] Chowdhury, R., Taneja, S., Kvestad, I., et al. (2020) Vitamin D Status in Early Childhood Is Not Associated with Cognitive Development and Linear Growth at 6-9 Years of Age in North Indian Children: A Cohort Study. Nutrition Journal, 19, Article No. 14. https://doi.org/10.1186/s12937-020-00530-2

[26] Mamani, M., Muceli, N., Ghasemi Basir, H.R., Vasheghani, M. and Poorolajal, J. (2017) Association between Serum Concentration of 25-Hydroxyvitamin D and Community-Acquired Pneumonia: A Case-Control Study. International Journal of General Medicine, 10, 423-429. https://doi.org/10.2147/IJGM.S149049

[27] Özdemir, B., Köksal, B.T., Karakaş, N.M., Tekindal, M.A. and Özbek, Ö.Y. (2016) Serum Vitamin D Levels in Children with Recurrent Respiratory Infections and Chronic Cough. The Indian Journal of Pediatrics, 83, 777-782. https://doi.org/10.1007/s12098-015-2010-1

[28] Naheed, A., Breiman, R.F., Islam, M.S., Saha, S.K. and Naved, R.T. (2019) Disparities by Sex in Care-Seeking Behaviors and Treatment Outcomes for Pneumonia among Children Admitted to Hospitals in Bangladesh. PLoS ONE, 14, e0213238. 
https://doi.org/10.1371/journal.pone.0213238

[29] Del Rosal, T., Caminoa, M.B., González-Guerrero, A., et al. (2020) Outcome of Severe Bacterial Pneumonia in the Era of Pneumococcal Vaccination. Frontiers in Pediatrics, 8, 576519. https://doi.org/10.3389/fped.2020.576519

[30] Yancey, A.L., Watson, H.L., Cartner, S.C. and Simecka, J.W. (2001) Gender Is a Major Factor in Determining the Severity of Mycoplasma Respiratory Disease in Mice. Infection and Immunity, 69, 2865-2871.

https://doi.org/10.1128/IAI.69.5.2865-2871.2001

[31] Bénet, T., Sylla, M., Messaoudi, M., et al. (2015) Etiology and Factors Associated with Pneumonia in Children under 5 Years of Age in Mali: A Prospective Case-Control Study. PLOS ONE, 10, e0145447.

https://doi.org/10.1371/journal.pone.0145447

[32] Weiler, H.A. (2017) Vitamin D Supplementation for Infants: Biological, Behavioural and Contextual Rationale. e-Library of Evidence for Nutrition Actions (eLENA), WHO.

[33] Feldstein, L.R., Rose, E.B., Horwitz, S.M., et al. (2020) Multisystem Inflammatory Syndrome in U.S. Children and Adolescents. The New England Journal of Medicine, 383, 334-346. https://doi.org/10.1056/NEJMoa2021680

[34] Mourad, S., Rajab, M., Alameddine, A., et al. (2010) Hemoglobin Level as a Risk Factor for Lower Respiratory Tract Infections in Lebanese Children. North American Journal of Medical Sciences, 2, 461-466. https://doi.org/10.4297/najms.2010.2461

[35] Rashad, M.M., Fayed, S.M. and El-Hag, A.M. (2015) Iron-Deficiency Anemia as a Risk Factor for Pneumonia in Children. Benha Medical Journal, 32, 96-100. https://doi.org/10.4103/1110-208X.180321

[36] Lakhani, D. and Muley, P. (2013) The Association of Positive Chest Radiograph and Laboratory Parameters with Community Acquired Pneumonia in Children. Journal of Clinical and Diagnostic Research, 7, 1629-1631. https://doi.org/10.7860/JCDR/2013/5132.3222

[37] Dufort, E.M., Koumans, E.H., Chow, E.J., et al. (2020) Multisystem Inflammatory Syndrome in Children in New York State. The New England Journal of Medicine, 383, 347-358. https://doi.org/10.1056/NEJMoa2021756

[38] Don, M. (2011) Risk Factors of Paediatric Community-Acquired Pneumonia. European Respiratory Journal, 37, 724-725; author reply 725. https://doi.org/10.1183/09031936.00164010

[39] Fink, C., Peters, R.L., Koplin, J.J., Brown, J. and Allen, K.J. (2019) Factors Affecting Vitamin D Status in Infants. Children, 6, 7. https://doi.org/10.3390/children6010007

[40] Gellert, S., Ströhle, A. and Hahn, A. (2017) Breastfeeding Woman Are at Higher Risk of Vitamin D Deficiency than Non-Breastfeeding Women-Insights from the German VitaMinFemin Study. International Breastfeeding Journal, 12, Article No. 19. https://doi.org/10.1186/s13006-017-0105-1

[41] Tan, M.L., Abrams, S.A. and Osborn, D.A. (2018) Vitamin D Supplementation for Term Breastfed Infants to Prevent Vitamin D Deficiency and Improve Bone Health. The Cochrane Database of Systematic Reviews, 12, CD013046. https://doi.org/10.1002/14651858.CD013046 